\title{
Occurrence and habitat use of European eel (Anguilla anguilla) in running waters: lessons for improved monitoring, habitat restoration and stocking
}

\author{
Erik Degerman (D) Carl Tamario $(\mathbb{D}) \cdot$ Johan Watz $(\mathbb{D})$ P. Anders Nilsson $(\mathbb{D})$ \\ Olle Calles 1
}

Received: 10 April 2019/Accepted: 31 July 2019/Published online: 7 August 2019

(C) The Author(s) 2019

\begin{abstract}
To improve the management of the European eel (Anguilla anguilla) in freshwater, it is essential to define important lotic habitats. Electrofishing data from 289 wadeable, hard-bottom sites in 69 Swedish coastal rivers and streams, originally surveyed for salmonid monitoring, were used to evaluate the effects of sampling- and habitat-related factors on eel occurrence. Probability of eel occurrence, as influenced by sampling procedure (sampled area, number of consecutive runs and ambient water temperature) and habitat characteristics (size of catchment, dominating bottom substrate, shade, water
\end{abstract}

Handling Editor: Télesphore Sime-Ngando.

E. Degerman $(\bowtie)$

Department of Aquatic Resources, Institute of Freshwater Research, Swedish University of Agricultural Sciences,

Stockholm, Sweden

e-mail: erik.degerman@slu.se

C. Tamario

Centre for Ecology and Evolution in Microbial Systems, EEMiS, Department of Biology and Environmental

Science, Linnaeus University, Kalmar, Sweden

J. Watz · P. A. Nilsson · O. Calles

River Ecology and Management Research Group RivEM, Department of Environmental and Life Sciences, Karlstad University, Karlstad, Sweden

P. A. Nilsson

Department of Biology - Aquatic Ecology, Lund

University, Lund, Sweden velocity, mean depth), was evaluated for small (total length $\leq 150 \mathrm{~mm})$ and large $(>150 \mathrm{~mm})$ yellow eels. Data were analysed in a mixed presence/absence generalized linear model with dispersal (distance to mouth from sampled site), habitat and samplingrelated variables as covariates. The two models explained variation in occurrence to $81.5 \%$ for small eel and $76.2 \%$ for large eel. Probability of eel occurrence decreased with distance from the river mouth, and increased with sampled area, number of runs, water temperature, coarser substrate and size of river. We suggest that future eel habitat restoration should focus on lower reaches of larger rivers with suitable coarse bottom habitats. Stocking of young eel should be carried out in comparable accessible habitats in the upper reaches where eel densities are low. The results also strongly indicate that eel may be sampled together with young salmonids with DC electrofishing in wadeable habitats.

Keywords Eel management · Electrofishing · River · Temperature $\cdot$ Restoration $\cdot$ Sampling $\cdot$ Stocking

\section{Introduction}

There has been a drastic decline in abundance of the European eel (Anguilla anguilla) (Dekker 2003a), with current recruitment at only $1-10 \%$ of that 
recorded in the 1980s (Jacoby and Gollock 2014). The negative development has been attributed to several causes, e.g. overexploitation (Moriarty and Dekker 1997; Jacoby et al. 2015), ocean climate change (Castonguay et al. 1994; Durif et al. 2011), pollutants (Feunteun 2002) and the effect of parasites (Sjöberg et al. 2009). In freshwater, the main causes of the decline are suggested to be poor function and placement of passes for eel immigrating to freshwater (Tamario et al. 2019; Watz et al. 2019), loss and deterioration of freshwater habitat (Feunteun 2002) and delay and mortality of maturing eel passing dams and power plants (Besson et al. 2016).

In 2007, the European Union decided to implement a stock protection plan (Council Regulation No 1100/2007). The regulation aims at decreasing all anthropogenic sources of mortality, with management targeting an escapement of at least $40 \%$ of the pristine biomass of silver eel leaving for spawning. To reach this goal, multiple conservation measures are needed. Decreased fishing of yellow and silver eels and facilitating the downstream migration of silver eel are prioritized actions in the Swedish eel management plan. Consequently, catchments prioritized in the management plan are mainly those with high estimated production of silver eels. This prioritization is logical, but to enhance eel recruitment, and thereby production, attention should also be paid to river systems with suitable habitats for immigrating elvers and young yellow eel. Moreover, the practice of assisted migration within river systems and stocking of elvers from other rivers, and even countries, should benefit from furthered knowledge on preferred habitats (e.g. Pedersen 2009; Matondo et al. 2019).

The eel larvae migrate from the spawning area in the Sargasso Sea and metamorphose into glass eel on arrival at the continental shelf (Tesch 2003). In spring, the glass eels transform into pigmented elvers. A proportion of elvers and young yellow eel colonize freshwaters. In freshwater, upstream migration depends on eel density and body sizes and is initiated by increasing water temperatures (Ibbotson et al. 2002; Imbert et al. 2010). Eels are facultative catadromous, i.e. eels may migrate to freshwater, but some reside in marine or brackish coastal waters until returning to the Sargasso Sea to spawn, and some individuals move between marine, estuarine and freshwater habitats (e.g. Arai et al. 2006, 2013; Benchetrit et al. 2017). In freshwater, a large variety of lake and river habitats are used (Moriarty and Dekker 1997; Tesch 2003; Benchetrit et al. 2017).

At the catchment scale, distribution and abundance of eel may be affected by the amount of elvers entering the river (Feunteun et al. 2003), the temperature of the river (Ogden 1970), water quality (Degerman et al. 1986), river discharge and velocity (Jessop 2000) and accessibility of habitats (Laffaille et al. 2009). Young eel (Anguilla spp.) in freshwater have been shown to prefer riverine habitats at the macrohabitat scale, where water depth, bottom substrate, vegetation roots and in-stream and bank vegetation cover are important (Lamouroux et al. 1999; Laffaille et al. 2003; Domingos et al. 2006; Graynoth et al. 2008; Acou et al. 2011; Ovidio et al. 2013). Several authors have also reported a size-related difference in river habitat use (e.g. Lamouroux et al. 1999; Laffaille et al. 2003; Graynoth et al. 2008), where smaller eel individuals may be more frequent in shallower (Laffaille et al. 2003) and peripheral areas (Graynoth et al. 2008), such as tributaries (Benchetrit et al. 2017).

Eel passes (generally in the form of eel ladders) have been established in several larger rivers in southern Sweden to facilitate immigration of elvers to freshwater. The maintenance and monitoring of these have, however, been inadequate (cf. Pärlklint and Bengtsson 2015) and their efficiency low (Tamario et al. 2019). Due to the large number of dams and the relatively few eel passes present, freshwater eel management has for decades relied mainly on assisted migration of elvers to lakes and streams upstream in the catchments. Elvers were often caught in a collection box in an eel ladder at the lowermost dam and transported upstream. With declining numbers of ascending elvers into Swedish rivers, elvers were routinely imported from other European countries (France, England) from the 1950s (Dekker et al. 2011; Dekker and Beulaton 2016). Few recent efforts have been made to facilitate natural immigration of young eel.

Eels are considered difficult to sample quantitatively (Dekker 2003b). The quantity of young eel immigrating to freshwater habitats has been monitored in some river mouths, using eel traps often connected to eel passes, while growing yellow eel in freshwater habitats has been paid less attention.

Electrofishing is often carried out in wadeable small- to medium-sized running waters to monitor salmonid recruitment. Baldwin and Aprahamian 
(2012) stated that surveys focusing on salmonids also can potentially give good estimates of eel abundance, and Reid (2011) showed that transect-based sampling is better than point-based sampling of eel occurrence and abundance. However, it has also been argued that data on eel from such programmes are inadequate, with low precision in abundance estimates (e.g. Bohlin et al. 1989). Eel may, for instance, be immobilized due to their length over the voltage gradient, reducing catchability (Zalewski and Cowx 1989), and stunned eel may be difficult to detect in water with low visibility (Koops 1980). However, data presented by Baldwin and Aprahamian (2012) showed relatively high $(>0.6)$ catch efficiency of eel after one electrofishing run, indicating that eel occurrence and abundance may not be as difficult to estimate as commonly regarded (Reid 2011; Acou et al. 2011).

In the present study, we tested the effect of different habitat factors on eel occurrence, using a national electrofishing database (Swedish Electrofishing RegiSter; SERS). Eel occurrence was assumed to depend on three factors: dispersal, sampling and habitat. The dispersal variable was evaluated as distance from the river mouth, representing a migration cost and general population thinning due to successive mortality and settling of eel in available habitats downstream of each site (e.g. Ibbotson et al. 2002; Feunteun et al. 2003; Imbert et al. 2008; Acou et al. 2011; Tamario et al. 2019). Sampling effort should affect detectability of a species, particularly at low densities, and should thereby be a key factor for reliable assessment (e.g. Degerman et al. 1986; Acou et al. 2011; Reid and Haxton, 2017). Moreover, the activity of eel decreases at water temperatures below c. 6-10 ${ }^{\circ} \mathrm{C}$ (Nyman 1972; Naismith and Knights 1988; Riley et al. 2011). Sampled area, the number of consecutive fishing runs and water temperature were thus included as predictive variables in the analyses. Habitat descriptors included in the analyses were dominating substrate, mean water depth, shade, water velocity and river size. The aim of this paper is threefold: (1) evaluate the habitat use of small $(\leq 150 \mathrm{~mm})$ and large ( $>150 \mathrm{~mm}$ ) eel during daytime in wadeable, hardbottom habitats during July to October, (2) provide recommendations for how to improve sampling/monitoring of eel using electrofishing and (3) give advice for future restoration of eel habitat in freshwater.

\section{Materials and methods}

Site selection

Data on eel occurrence were obtained from the Swedish Electrofishing RegiSter (SERS). Only data from the west coast of Sweden were included, as immigration of eel is substantially lower on the east coast-the Baltic Sea area (Moriarty and Dekker 1997; Dekker et al. 2011). Site selection was restricted to downstream of the first impassable migration barrier for sea-migrating salmonids and eel. Data on migration barriers were acquired from the database SERS, from personal information from fisheries officers, Tamario et al. (2019) and Pärlklint and Bengtsson (2015).

Sampling occasions included were from 1st of July to 31 st of October of the years 1990 to 2016. Sites directly subjected to eel stocking (pers. comm. Ph. D. Håkan Wickström, national database on eel stocking) were excluded. Some sites were electrofished only one year, while others were fished several years. If a site was fished several times during a single year (less than $0.5 \%$ of sites), the sampling occasion closest to 3rd of September (the median sampling date in the material) was selected for that site and year.

In total 1611 fishing occasions from 289 sites in 68 individual streams and rivers were included in the data set (Fig. 1). 9.1\% of fishing occasions were performed in July, 35.8\% in August, $41.5 \%$ in September and $13.5 \%$ in October. The median annual air temperature in the area sampled was $7.0{ }^{\circ} \mathrm{C}$, with median annual precipitation of $766 \mathrm{~mm}$ (Swedish Hydrological and Meteorological Institute).

\section{Sampling}

Eel occurrence (yes/no) was evaluated instead of abundance, as older data did not separate caught eel between different fishing runs, and sometimes only minimum and maximum lengths were recorded, making abundance estimates of different length classes impossible. Data quality in the register is assured through a standardized sampling process (Bergquist et al. 2014) and centralized quality control at SERS. Most electrofishing data in the Swedish programme originate from monitoring programmes focusing on Atlantic salmon (Salmo salar) and brown trout (S. trutta). Electrofishing surveys were carried 
Fig. 1 Site distribution on the west coast of Sweden. The latitude of sites was N55.55 to N59.07 and longitude E11.15 to E13.33, corresponding to $380 \mathrm{~km}$ between the sites farthest apart

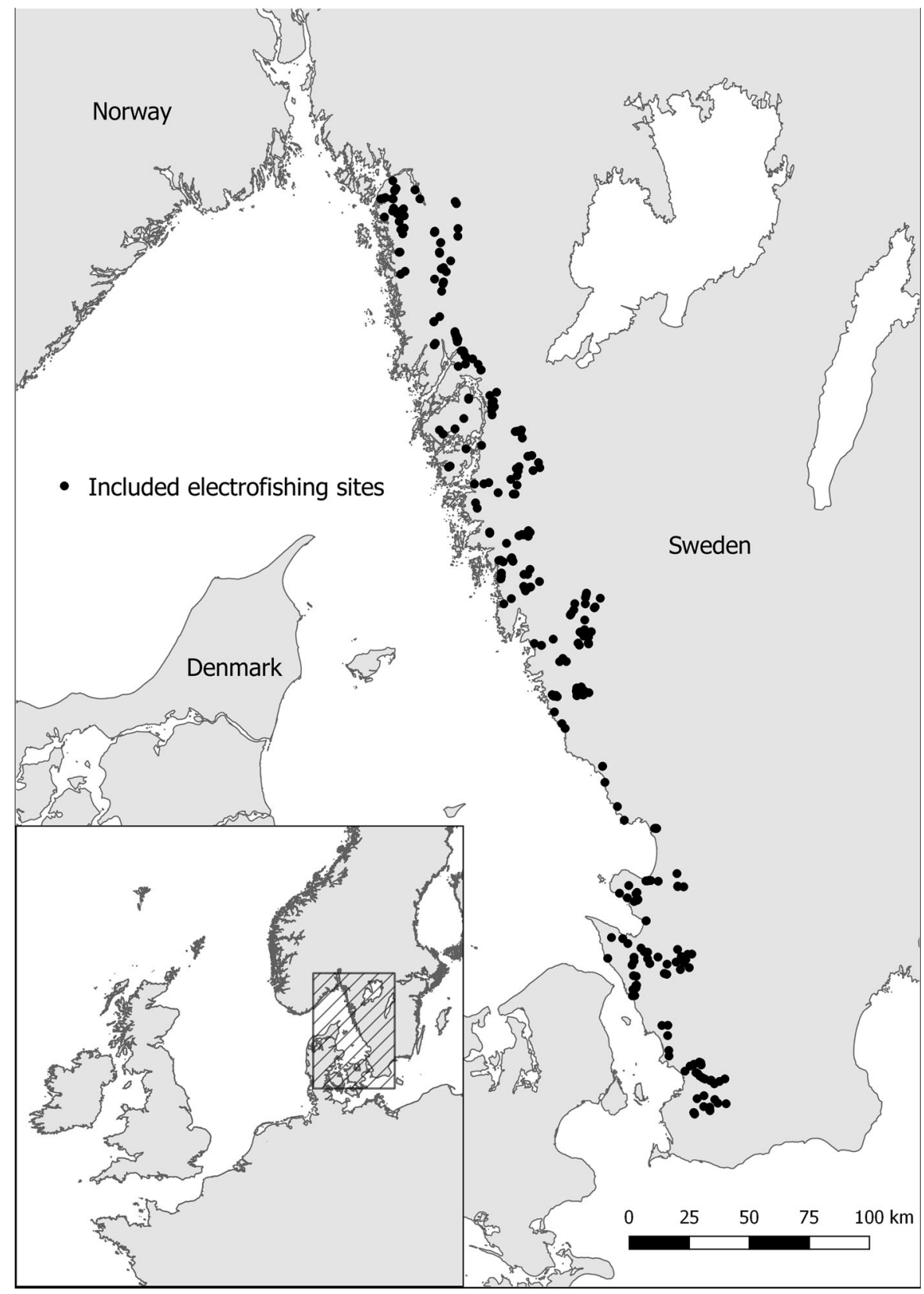

out by two to three people wading with a single, handheld anode using non-pulsed DC at 200-800 V (depending on conductivity). Sites sampled with battery-powered gear using pulsed DC were omitted from analyses as this may lead to increased stunning of eels and thereby potentially reduced catchability (Tesch 2003). Electrofishing sampling was performed according to national standards (Bergquist et al. 2014), e.g. transect-based sampling, voltage used, season, fish handling, site description and standardized field protocols. All fish are normally measured to the nearest millimetre (total length) and released alive. However, in earlier (1990s) surveys, eels were sometimes only measured to the nearest $\mathrm{cm}$. In the present work, occurrences of newly immigrated eel (elvers, typically $\leq 150 \mathrm{~mm}$; Acou et al. 2011) as well as larger $(>150 \mathrm{~mm})$ yellow eel were used in analyses. 
For each sampling of a site, sampled area, number of consecutive electrofishing runs and water temperature were extracted from the database. Site-specific habitat was described with average depth $(\mathrm{m})$, average wetted width $(\mathrm{m})$, dominating bottom substrate (scored from 1 to 7 ; fine: $<0.2 \mathrm{~mm}$, sand: 0.2-2 mm, gravel: $2.1-20 \mathrm{~mm}$, small stones: 20.1-100 mm, large stones: 101-200 mm, small boulders: 201-400 mm, large boulders $>400 \mathrm{~mm}$ ), surface water velocity, shaded proportion (\%) of the sampling site and river catchment size. Surface water velocity (average of site) was categorized into slow (1), intermediate (2) and fast (3), with class boundaries at approximately $0.2 \mathrm{~m} / \mathrm{s}$ and $0.7 \mathrm{~m} / \mathrm{s}$. Shaded proportion of each electrofished site was approximated to the nearest $10 \%$. Size of catchment area $\left(\mathrm{km}^{2}\right)$ upstream site was used as a large-scale habitat variable. As a dispersal variable, the distance from the sea $(\mathrm{km})$ along the river to each site was measured with GIS.

\section{Statistical methods}

A generalized linear mixed model approach with a binomial distribution and logit link function with repeated measures was used (GENLINMIXED in IBM SPSS version 22) to evaluate the probability distribution of eel occurrence depending on the independent dispersal, sampling and habitat variables. Electrofishing sites were nested within main catchments and specified as lowest-level subjects with "year" assigned as a repeated measure variable. The repeated measures covariance structure was specified as "diagonal". Main catchment was specified as a random block effect with random intercept to address inter-river variation. Since the data were unbalanced, robust variance components were chosen for the testing of fixed effects and coefficients. To test for multicollinearity among explanatory variables, the variance inflation factor (VIF) was analysed in R using the "vif"-function from package "usdm". No included variable showed VIF higher than 1.5 , indicating no bias from multicollinearity among explanatory variables. Visual inspection of the autocorrelation of residuals from repeatedly sampled sites showed no systematic pattern.

In the models, dominating substrate size, water velocity and number of electrofishing runs were used as ordinal factorial variables. Water temperature, sampled area, distance to sea, shade and catchment area were used as continuous variables. Positively skewed continuous variables (sampled area, distance to sea and catchment area) were log-transformed to reduce residual nonlinearity and heteroscedasticity.

Occurrences of small and large eel were analysed separately. In the first analysis, all variables describing dispersal, sampling and habitat were included. If any variable was not significant in the resulting model, it was eliminated and the model re-analysed with the remaining variables. This was repeated until all included variables in the model were significant.

Results presented for individual variables are estimated marginal means (where all other variables are kept at their mean) or predicted probability of occurrence for each site from the GLMM. Comparison of classes of predicted occurrence at the sites was carried out with one-way analysis of variance (ANOVA) with $\mathrm{S}-\mathrm{N}-\mathrm{K}$ post hoc test.

\section{Results}

Site features and eels captured

The included streams and rivers were generally small, with a median upstream catchment area of $19.9 \mathrm{~km}^{2}$ (Table 1). The site farthest away from the sea was situated $48.9 \mathrm{~km}$ upstream, but the median distance to sea was only $12.3 \mathrm{~km}$. The mean depth of sampled sites varied between 0.04 and $0.9 \mathrm{~m}$, with a median of $0.22 \mathrm{~m}$. Electrofishing sites were biased towards shallow water as a consequence of sampling being carried out by wading.

Dominating substrate had a median score of 4 , corresponding to small stones, occurring at $28.4 \%$ of fishing occasions. Large stones $(21.2 \%)$ and gravel (15.2\%) were also frequent. No dominating substrate class occurred at less than $7.4 \%$ (fine) of the sampling occasions.

Eel (of any size class) was caught on $862(53.5 \%)$ out of 1611 fishing occasions; small eel at $30.7 \%$ of all 1611 occasions and large eel at $48.0 \%$. For the fishing occasions when all eels were measured $(n=795)$, the mean length of the 6736 eels was $210 \mathrm{~mm}$ (SD \pm 107). Of these, the mean length of small $(\leq 150 \mathrm{~mm})$ eel was $113 \mathrm{~mm}(\mathrm{SD} \pm 23)$, and the mean length of large $(>150 \mathrm{~mm})$ eel was $265 \mathrm{~mm}(\mathrm{SD} \pm 96)$. Of the 
Table 1 Descriptive statistics of included explanatory variables

Log10-transformed variables (denoted with *) were back-transformed for clarity

Arithmetic mean, standard deviation (SD), median, minimum and maximum values given

\begin{tabular}{llllllll}
\hline Variable & Type & Factor & Mean & SD & Median & Min & Max \\
\hline Distance to mouth* $^{*}$ & Continuous, km & Dispersal & 7.8 & 4.5 & 12.3 & 0.1 & 48.9 \\
Sampled area* $^{*}$ & Continuous, ${ }^{2}$ & Sampling & 120.2 & 2.0 & 114.8 & 4.0 & 1949 \\
Number of runs & Factor, 1-3 & Sampling & 2.58 & 0.69 & 3 & 1 & 3 \\
Water temperature & Continuous, ${ }^{\circ} \mathrm{C}$ & Sampling & 14.4 & 3.4 & 14.7 & 2.6 & 24.1 \\
Catchment area* & Continuous, km ${ }^{2}$ & Habitat & 34.7 & 5.4 & 19.9 & 1.0 & 2041 \\
Substrate & Factor, 1-7 & Habitat & 4.04 & 1.59 & 4 & 1 & 7 \\
Mean depth & Continuous, m & Habitat & 0.24 & 0.12 & 0.22 & 0.04 & 0.90 \\
Shade & Continuous, $\%$ & Habitat & $59 \%$ & $30 \%$ & $70 \%$ & $0 \%$ & $100 \%$ \\
Water velocity & Factor, 1-3 & Habitat & 2.23 & 0.64 & 2 & 1 & 3 \\
\hline
\end{tabular}

measured eels, $4.7 \%$ were $400 \mathrm{~mm}$ or larger and $1.6 \%$ were $500 \mathrm{~mm}$ or larger.

Generalized linear mixed models

Water velocity and shade (proportion of the sampled site shaded) were not significant in the initial model for either small or large eel and were eliminated from further analysis. The resulting models included all remaining explanatory variables. The occurrence of small eel could be correctly predicted for $81.5 \%$ of fishing occasions (GLMM $\quad \mathrm{F}_{13,1597}=28.80$, $p<0.001)$ and for large eel $76.2 \%\left(\mathrm{~F}_{13,1597}=25.74\right.$, $p<0.001)$.

The probability of occurrence of eel decreased significantly with distance from river mouth (Table 2). Occurrence increased with sampled area and number of fishing, both for small and large eel. The estimated marginal means of probability of eel occurrence was more than double at sites where two runs were carried out compared to one run, whereas the difference between two and three runs was non-significant (Table 3). The probability of catching eel increased with water temperature during sampling (Fig. 2). No eel was caught at temperatures below $7^{\circ} \mathrm{C}$.

Catchments $\leq 100 \mathrm{~km}^{2}$ generally had lower predicted occurrence than larger catchments (Table 4). There was no significant difference in predicted occurrence between catchments of 101-1000 km² and $1001-2041 \mathrm{~km}^{2}$ for either small or large eel (ANOVA, post hoc SNK, $p>0.05$ ), while smaller catchments had significantly lower occurrence $(p<0.05)$.

For both small and large eel, probability of occurrence increased with increasing substrate size from fine to stony substrate. For small eel, the
Table 2 GLMM model results ( $F$ values, degrees of freedom, $p$ values) for significant explanatory variables for small and large eel

Linear trend in occurrence with increased value of variable is also given

\begin{tabular}{llcccl}
\hline Cohort & Variable & $F$ & $d f 1+d f 2$ & Sign. & Occurrence \\
\hline Large eel & Distance to mouth & 11.89 & $1+1597$ & 0.001 & Decreases \\
Small eel & & 9.91 & & 0.002 & Decreases \\
Large eel & Catchment area & 42.24 & $1+1597$ & $<0.001$ & Increases \\
Small eel & & 47.294 & & $<0.001$ & Increases \\
Large eel & Substrate & 2.786 & $6+1597$ & 0.011 & Increases \\
Small eel & & 4.607 & & $<0.001$ & Increases \\
Large eel & Mean depth & 4.346 & $1+1597$ & 0.037 & Increases \\
Small eel & & 10.96 & & $<0.001$ & Increases \\
Large eel & Water temperature & 25.275 & $1+1597$ & $<0.001$ & Increases \\
Small eel & & 15.20 & & $<0.001$ & Increases \\
Large eel & Sampled area & 46.501 & $1+1597$ & $<0.001$ & Increases \\
Small eel & & 16.34 & & $<0.001$ & Increases \\
Large eel & Number of runs & 3.626 & $2+1597$ & 0.027 & Increases \\
Small eel & & 7.55 & & 0.001 & Increases \\
\hline
\end{tabular}


Table 3 Estimated marginal means $( \pm 95 \%$ confidence interval) for probability of catching an eel (eel occurrence) at fishing occasions when one, two or three consecutive runs were carried out

\begin{tabular}{llll}
\hline & 1 run & 2 runs & 3 runs \\
\hline Small eel & $0.074(0.058)$ & $0.261(0.126)$ & $0.249(0.088)$ \\
Large eel & $0.285(0.134)$ & $0.519(0.116)$ & $0.532(0.088)$ \\
\hline
\end{tabular}

The number of observations in the three classes was: 186, 305 and 1120 , respectively. All other significant variables were held at their mean (Table 1)

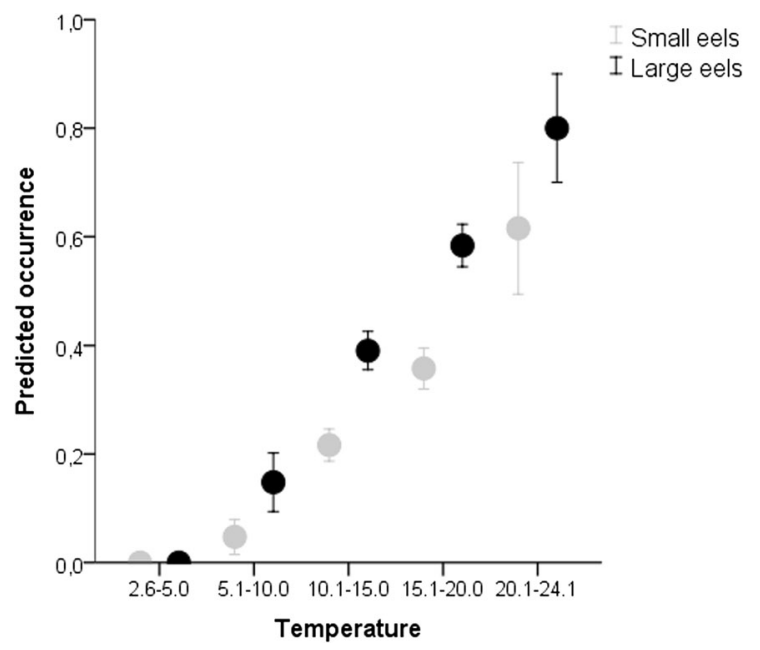

Fig. 2 Predicted probability of occurrence of eel (with 95\% confidence intervals), small eel (grey) and large eel (black), from GLMM plotted against water temperature during sampling

predicted occurrence did not differ between areas with large stones or small and large boulders, whereas the occurrence of large eel increased with increasing substrate size throughout the substrate size classes (Fig. 3). The occurrence of both size classes of eel showed low and comparable probabilities of occurrence for fine and sandy substrates, indicating low use of areas dominated by finer substrate classes.

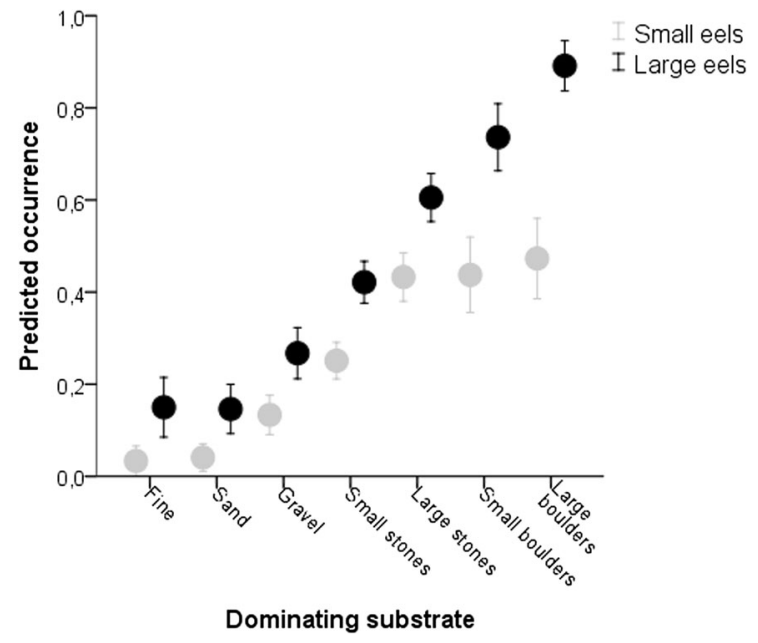

Fig. 3 Predicted probability of occurrence (from GLMM, \pm 95\% CI) of small (grey) and large (black) eel for different dominating substrate size categories

Probability of occurrence of small and large eel increased significantly with mean water depth of the electrofished site down to a depth of $0.4 \mathrm{~m}$, below which predicted occurrence decreased (Fig. 4). Predicted occurrences differed significantly between mean depths for both small (ANOVA, $\left.F_{4,1606}=35.3, \quad p<0.001\right) \quad$ and large eel $\left(F_{4,1606}=45.9, p<0.001\right)$, while the difference in probability of occurrence between mean depths of $0.31-0.40 \mathrm{~m}$ and $>0.40$ was significant for small eel, but not for large eel (ANOVA, $p<0.001$ and $p=0.25$, respectively).

\section{Discussion}

Dispersal and restoration prioritization

The probability of eel occurrence decreased significantly with increasing distance from the sea,

Table 4 Predicted probability of occurrence of eel ( $\pm 95 \%$ confidence intervals) from the GLMM at sites with different catchment areas upstream

\begin{tabular}{lllll}
\hline & \multicolumn{3}{l}{ Catchment area $\left(\mathrm{km}^{2}\right)$} & \\
\cline { 2 - 5 } & $1-10 \mathrm{~km}^{2}$ & $11-100 \mathrm{~km}^{2}$ & $101-1000 \mathrm{~km}^{2}$ & $1001-2041 \mathrm{~km}^{2}$ \\
\hline Small eel & $0.04(0.19)$ & $0.12(0.33)$ & $0.72(0.45)$ & $0.78(0.41)$ \\
Large eel & $0.07(0.26)$ & $0.38(0.49)$ & $0.95(0.21)$ & $0.97(0.17)$ \\
\hline
\end{tabular}

The number of catchments in the four classes was 460, 705, 344 and 102, respectively 


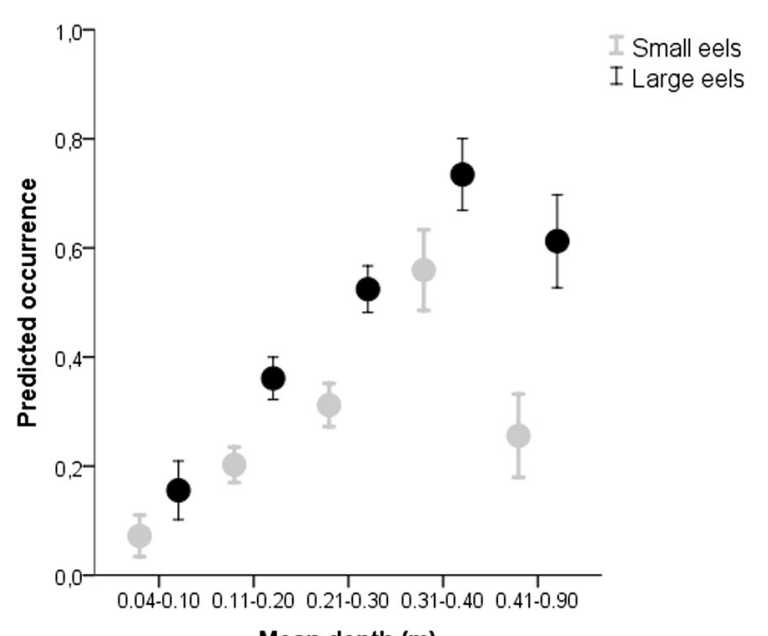

Mean depth (m)

Fig. 4 Predicted probability of occurrence of eels (with $95 \%$ confidence intervals), small (grey) and large (black) eel, from GLMM plotted against mean depth (m)

corroborating previous work (Ibbotson et al. 2002; Imbert et al. 2008; Acou et al. 2011; Tamario et al. 2019), in spite of sampled sites being accessible and located relatively close to the sea (maximum distance $48.9 \mathrm{~km}$ ). This pattern could be an effect of a low eel population density where competition for resources and habitat is low and thus does not drive individuals to further upstream migration to find suitable habitat (Ibbotson et al. 2002; Feunteun et al. 2003; Jellyman and Arai 2016; Matondo et al. 2019). Assuming such density-dependent migration and habitat use patterns, habitat restoration incentives should prioritize more downstream river stretches at the currently low eel recruitment levels and eventually shift to more upstream stretches upon future eel population recovery. Current assisted migration and stocking programmes should aim for available suitable habitats further upstream for efficiency and to minimize possible density-dependent competition with naturally immigrating eel.

The presented data moreover strongly indicate that the probability of occurrence of eel is positively related to river size. Large volumes of freshwater on the coast may attract migrating glass eel and elvers to a greater extent than low flows (Sorensen 1986; Piper et al. 2012). Larger rivers may also enhance upstream migration at natural obstacles and tend to have lower slopes than small streams, facilitating upstream migration. Possible higher attraction and facilitated freshwater migration suggest that larger rivers should be prioritized in future eel recovery programmes aiming for improved upstream passage and habitats.

\section{Habitat use}

Habitat use by eel may shift with body size and season (Johnson and Nack 2013; Jellyman and Arai 2016). The results in this study show similar, but not identical, daytime habitat use of small and large eel as in other studies (cf. Barak and Mason 1992). The effect of water velocity was not significant in the data, probably as velocities were estimated as site-specific averages, often without using flow meters. Thus, the quality of the water velocity data was poor and with few and broad classes. Further, for the benthic eel, the bottom conditions should be more important than water surface velocity, especially during daytime when eels are less active.

The macrohabitat variables 'dominating substrate' and 'mean water depth' influenced the probability of eel occurrence. For both size classes of eel, the predicted occurrence increased with mean depth up to $0.31-0.40 \mathrm{~m}$. Small fish should be more vulnerable to predation than large fish, and thus, it should be beneficial for small eel to use shallow habitats (cf. Bohlin 1977) to avoid predation. The present results indicate that small eel reside at shallow depths during daytime. This depth use could be a response to terrestrial, aerial and aquatic predators (Barak and Mason 1992). In a New Zealand lake, juvenile shortfinned eel (Anguilla australis) used shallow areas in the lake's margins, whereas larger eel were found all over the lake (Jellyman and Chisnall 1999).

Jellyman and Arai (2016) concluded that large eels are habitat generalists, and Tesch (2003) even stated that eels may be found in all available habitats, at least if the oxygen demand is fulfilled (Moriarty 2003). Without contradicting these findings, the probability of eel occurrence in our study was significantly higher in specific riverine habitats than others. Moreover, our results are corroborated in an experimental study of elvers in marine habitat, where coarse substrate was preferred (Christoffersen et al. 2018). In experimental studies on yellow eel, Nyman (1972) showed that eels were highly selective with regard to bottom substrate, with a shift from hibernating in soft bottom (mud) at low temperatures to hiding in coarse bottom substrate at water temperatures $>8-9{ }^{\circ} \mathrm{C}$. Other studies have also shown that soft substratum can be used as shelter 
by anguillids (Jellyman and Chisnall 1999; Aoyama et al. 2005; Acou et al. 2011), especially in lakes (Scott and Crossman 1973). However, Fischer and Eckmann (1997) found the highest summer densities of eel in Lake Constance, Germany, at a site with boulders. There was a tendency in the present study that large eel more frequently used coarser substrate than small eel, probably an adaptation to the need for larger burrows/ crevices with increasing body size.

Overhead cover has been shown to be important for eels (Acou et al. 2011; Johnson and Nack 2013), but in this study, shade had no significant effect of eel daytime occurrence. This result indicates that the shading effect of trees and bushes in the riparian zone may be of lesser importance, perhaps as eels are diurnally inactive. However, the riparian zone also provides organic matter to the rivers. In a study on American eel (Anguilla rostrata), Johnson and Nack (2013) found that areas acting as deposition zones for deciduous leaf litter in the autumn were important eel habitat. All sizes of eel used leaf litter as overhead cover in autumn, as compared to hiding in coarser substrates during the summer. This autumn habitat use indicates that there may be a significant effect of the riparian zone to eel habitat quality during other seasons of the year than the summer to early autumn period investigated in our study.

Salmonids and eel-habitat use and potential interactions

The electrofishing data evaluated in this work originally focused on abundance estimates of salmonids (Salmo salar and S. trutta). The results show that typical areas for juvenile salmonids, i.e. hard-bottom substrates in running waters (Armstrong et al. 2003), are also used by eel during summer to early autumn. Tamario et al. (2018), moreover, demonstrated that fishways in the form of bypasses, mimicking natural running waters with hard bottom substrate, were used as habitat by both salmonids and eel. Eel preferred relatively low gradients (Tamario et al. 2018), i.e. probably slow water velocities, likely because they are poor swimmers (Solomon and Beach 2004). It should, however, be noted that high water velocities may act as a daytime refuge from predators and could be beneficial to eels if they stay hidden in the substrate or in burrows/crevices.
It has been argued that as eel and salmonids share habitats, eel predation on salmonids may hamper salmonid populations (see historical references within Dekker and Beulaton 2016). Cullen and McCarthy (2007), however, found no evidence of this and stated that eel in riffle habitats mainly feed on macroinvertebrates. Eel may undergo an ontogenetic diet shift from invertebrates to fish at a length of $c .400 \mathrm{~mm}$ (Mann and Blackburn 1991; Schulze et al. 2004). In the present data, only $5 \%$ of measured eels were $400 \mathrm{~mm}$ or larger, indicating that the effect of eel predation on young salmonids in riverine habitats could be viewed as low. It is, moreover, reasonable to assume that eel shift habitat use when they outgrow the shallow habitat and perhaps need access to large prey, e.g. fish (Prchalová et al. 2013). Lentic habitats, such as lakes, slow-flowing river sections or estuaries may then be more important (e.g. Arai et al. 2006), alleviating the risk of eel predation on salmonids in their recruitment habitats.

\section{Sampling}

Electrofishing was carried out during the day, which means that the present results are representative for eel diurnal habitat use, which may differ from nocturnal habitat use (Johnson and Nack 2013). Most fish sampling techniques have limitations, and the risk of stunning eels before they can be collected with a dip net has been pointed out (Zalewski and Cowx 1989). Electrofishing with flat DC reduces this risk, as it does not stun eel to the same extent as pulsed DC or AC electrofishing (Tesch 2003).

We evaluated eel occurrence, instead of density, to minimize effects of sampling issues and to allow for extended data inclusion, but sampling-related factors still had a significant effect on the results. The results show that the area sampled (Angermeier and Smogor 1995) and the number of electrofishing runs (Trigal and Degerman 2015) are crucial predictors of eel occurrence. The probability of occurrence increased with area sampled and was lowest at sites sampled with only one electrofishing run (Carss et al. 1999). The latter result is likely explained by eel hiding before being disturbed and mobilized by the first fishing run, why at least two consecutive electrofishing runs should be carried out to improve catchability and accuracy of occurrence estimates. 
There was a substantial negative effect of lower water temperatures on catchability of eel. The strong effect of temperature on eel occurrence was expected (Nyman 1972; Trigal and Degerman 2015), as the eel is considered a warm-water species (Tesch 2003; Dekker 2003b). Riley et al. (2011) found no eel moving at temperatures below $10{ }^{\circ} \mathrm{C}$ in an English chalk stream, and Feunteun et al. (2003) indicate an activity threshold at $6-12{ }^{\circ} \mathrm{C}$, while Nyman (1972) found a threshold at $5-8{ }^{\circ} \mathrm{C}$ in an experimental set-up. In the present study, $7{ }^{\circ} \mathrm{C}$ was the lower limit for catching eel by electrofishing. In order to maximize the probability of catching of eel, sampling should be conducted at higher water temperatures, i.e. during summer. This, however, does not generally directly coincide with salmonid electrofishing surveys, which are carried out in August-September when young-ofthe-year salmonids are of catchable size (Bergquist et al. 2014). The present study, nevertheless, indicates that sampling young salmonids with DC electrofishing will also produce reliable estimates of yellow eel occurrence, but that the effects of temperature, number of runs and sampled area have to be considered. Since the daytime habitat use of eel resembles that of juvenile salmon (cf. Armstrong et al. 2003), efforts to sample both species could be combined.

Future sampling

As eel in freshwater also use lentic habitats and lakes, future sampling should include also these habitats, with quantitative and comparable methods. Electrofishing by wading is shown, in both the present study and several other studies, to be an accurate method (Reid 2011; Baldwin and Aprahamian 2012). Therefore, extending electrofishing sampling to deeper habitats and lakes using boat electrofishing may give new insights into eel habitat use and could probably give quantitative estimates of abundance.

Acknowledgements Open access funding provided by Swedish University of Agricultural Sciences. We wish to thank Dr. Willem Dekker for valuable comments to an earlier version of the manuscript, and Dr. Håkan Wickström for unpublished data on eel stocking. Both work at the Swedish University of Agricultural Sciences, Institute of freshwater research. Two anonymous referees further helped us to improve the manuscript. This work was financially supported by Svenska Forskningsrådet Formas (2015-824 and 2017-00346) and Stiftelsen Oscar och Lili Lamms Minne (DO2017-0050). Data are accessible through the authors and via www.gbif.org.

\section{Compliance with ethical standards}

Conflict of interest The authors declare that they have no conflict of interest.

Open Access This article is distributed under the terms of the Creative Commons Attribution 4.0 International License (http:// creativecommons.org/licenses/by/4.0/), which permits unrestricted use, distribution, and reproduction in any medium, provided you give appropriate credit to the original author(s) and the source, provide a link to the Creative Commons license, and indicate if changes were made.

\section{References}

Acou A, Rivot E, van Gils JA, Legault A, Ysnel F, Feunteun E (2011) Habitat carrying capacity is reached for the European eel in a small coastal catchment: evidence and implications for managing eel stocks. Freshw Biol 56(5):952-968

Angermeier PL, Smogor RA (1995) Estimating number of species and relative abundances in stream-fish communities: effects of sampling effort and discontinuous spatial distributions. Can J Fish Aquat Sci 52:936-949

Aoyama J, Shinoda A, Sasai S, Miller MJ, Tsukamoto K (2005) First observations of the burrows of Anguilla japonica. J Fish Biol 67:1534-1543

Arai T, Kotake A, McCarthy TK (2006) Habitat use by the European eel Anguilla anguilla in Irish waters. Estaurine Coast Shelf Sci 67:569-578

Arai T, Chino N, Le Quang D (2013) Migration and habitat use of the tropical eels Anguilla marmorata and A. bicolor in Vietnam. Aquat Ecol 47:57-65

Armstrong JD, Kemp PS, Kennedy GJA, Ladle M, Miller NJ (2003) Habitat requirements of Atlantic salmon and brown trout in rivers and streams. Fish Res 62:143-170

Baldwin L, Aprahamian M (2012) An evaluation of electric fishing for assessment of resident eel in rivers. Fish Res 123-124:4-8

Barak NE, Mason CF (1992) Population density, growth and diet of eels, Anguilla anguilla L., in two rivers in eastern England. Aquat Fish Manag 23:59-70

Benchetrit J, Beguer-Pon M, Sirois P, Castonguay M, Fitzsimons J, Dodson JJ (2017) Using otolith microchemistry to reconstruct habitat use of American eels Anguilla rostrata in the St. Lawrence river-lake Ontario system. Ecol Freshw Fish 26(1):19-33

Bergquist B, Degerman E, Petersson E, Sers B, Stridsman S, Winberg S (2014) Aqua reports 2014: code of practizeelectrofishing. In: Swedish. ISBN: 978-91-576-9275-7

Besson ML, Trancart T, Acou A, Charrier F, Mazel V, Legault A, Feunteun E (2016) Disrupted downstream migration behavior of European silver eels (Anguilla anguilla, L.) in an obstructed river. Environ Biol Fish 99:779-791

Bohlin T (1977) Habitat selection and intercohort competition of juvenile sea-trout Salmo trutta. Oikos 29(1):112-117

Bohlin T, Hamrin S, Heggberget TG, Rasmussen G, Saltveit SJ (1989) Electrofishing - theory and practice with special emphasis on salmonids. Hydrobiologia 173(1):9-43 
Carss DN, Elston DA, Nelson KC, Kruuk H (1999) Spatial and temporal trends in unexploited yellow eel stocks in two shallow lakes and associated streams. J Fish Biol 55(3):636-654

Castonguay M, Hodson PV, Moriarty C, Drinkwater KF, Jessop BM (1994) Is there a role of ocean environment in American and European eel decline? Fish Oceanogr 3:197-203

Christoffersen M, Svendsen JC, Kuhn JA, Nielsen A, Martjanova A, Stottrup JG (2018) Benthic habitat selection in juvenile European eel Anguilla anguilla: implications for coastal habitat management and restoration. J Fish Biol 93:996-999

Cullen P, McCarthy TK (2007) Eels (Anguilla anguilla (L.)) of the lower river Shannon, with particular reference to seasonality in their activity and feeding ecology. Biol Environ Proc R Irish Acad 107B(2):87-94

Degerman E, Fogelgren JE, Tengelin B, Thörnelöf E (1986) Occurrence of salmonid parr and eel in relation to water quality in small streams on the west coast of Sweden. Water Air Soil Pollut 30:665-671

Dekker W (2003a) Did lack of spawners cause the collapse of the European eel, Anguilla anguilla? Fish Manag Ecol $10: 365-376$

Dekker W (2003b) On the distribution of the European eel (Anguilla anguilla) and its fisheries. Can J Fish Aquat Sci 60(7):787-799

Dekker W, Beulaton L (2016) Faire mieux que la nature? The history of eel restocking in Europe. Environ Hist 22:255-300

Dekker W, Wickström H, Andersson J (2011) Status of the eel stock in Sweden in 2011. Aqua reports 2011:2, 66 p. In: Swedish. ISBN: 978-91-576-9052-4

Domingos I, Costa JL, Costa MJ (2006) Factors determining length distribution and abundance of the European eel, Anguilla anguilla, in the River Mondego (Portugal). Freshw Biol 51:2265-2281

Durif CMF, Gjøsaeter J, Vøllestad LA (2011) Influence of oceanic factors on Anguilla anguilla (L) over the twentieth century in coastal habitats of the Skagerrak, southern Norway. Proc R Soc B Biol Sci 278(1704):464-473

Feunteun E (2002) Management and restoration of European eel population (Anguilla anguilla): an impossible bargain. Ecol Eng 18:575-591

Feunteun E, Laffaille P, Robinet T, Briand C, Baisez A, Olivier JM, Acou A (2003) A review of upstream migration and movements in inland waters by anguillid eels: toward a general theory. In: Aida K, Tsukamoto K, Yamauchi K (eds) Eel biology. Springer, Tokyo, pp 191-213

Fischer P, Eckmann R (1997) Spatial distribution of littoral fish species in a large European lake, Lake Constance, Germany. Archive für Hydrobiologie 140(1):91-116

Graynoth E, Francis R, Jellyman DJ (2008) Factors influencing juvenile eel (Anguilla spp.) survival in lowland New Zealand streams. N Z J Marine Freshw Res 42(2):153-172

Ibbotson A, Smith J, Scarlett P, Aprahamian MW (2002) Colonisation of freshwater habitats by the European eel Anguilla anguilla. Freshw Biol 47:1696-1706

Imbert H, de Lavergne S, Gayou F, Rigaud C, Lambert P (2008) Evaluation of relative distance as new descriptor of yellow European eel spatial distribution. Ecol Freshw Fish 17(4):520-527
Imbert H, Labonne J, Rigaud C, Lambert P (2010) Resident and migratory tactics in freshwater European eels are size-dependent. Freshw Biol 55(7):1483-1493

Jacoby D, Gollock M (2014) Anguilla anguilla. The IUCN red list of threatened species 2014: e.T60344A45833138. https://doi.org/10.2305/IUCN.UK.2014-1.RLTS. T60344A45833138.en

Jacoby D, Casselman JM, Crook V, DeLucia MB, Ahn H, Kaifu K, Kurwie T, Sasal P, Silfvergrip AMC, Smith KG, Uchida K, Walker AM, Gollock MJ (2015) Synergistic patterns of threat and the challenges facing global anguillid eel conservation. Glob Ecol Conserv 4:321-333

Jellyman DJ, Arai T (2016) Juvenile eels: upstream migration and habitat use. In: Arai T (ed) Biology and ecology of anguillid eels. Taylor and Francis group, Routledge, pp 143-170

Jellyman DJ, Chisnall BL (1999) Habitat preferences of shortfinned eels (Anguilla australis), in two New Zealand lowland lakes. NZ J Mar Freshwat Res 33:233-248

Jessop BM (2000) Estimates of population size and instream mortality rate of American eel elvers in a Nova Scotia river. Trans Am Fish Soc 129:514-526

Johnson JH, Nack CC (2013) Habitat use of American eel (Anguilla rostrata) in a tributary of the Hudson River, New York. J Appl Ichthyol 29:1073-1079

Koops H (1980) Chapter 11. Sampling eels. In: Backiel T \& Welcomme RL (eds) Guidelines for sampling fish in inland waters. EIFAC 1980 Technical Paper (33):176 p

Laffaille P, Fuenteun E, Baisez A, Robinet T, Acou A, Legault A, Lek S (2003) Spatial organization of European eel (Anguilla anguilla L.) in a small catchment. Ecol Freshw Fish 12(4):254-264

Laffaille P, Lasne E, Baisez A (2009) Effects of improving longitudinal connectivity on colonization and distribution of European eel in the Loire catchment, France. Ecol Freshw Fish 8:610-619

Lamouroux N, Capra H, Pouilly M, Souchon Y (1999) Fish habitat preferences in large streams of southern France. Freshw Biol 42:673-687

Mann RHK, Blackburn JH (1991) The biology of the eel Anguilla anguilla (L.) in an English chalk stream and interactions with juvenile trout Salmo trutta L. and salmon Salmo salar L. Hydrobiologia 218:65-76

Matondo BN, Séleck E, Dierckx A, Benites JP, Rollin X, Ovidio M (2019) What happens to glass eels after restocking in upland rivers? A long-term study on their dispersal and behavioral traits. Aquat Conserv Marine Freshw Ecosyst 2019:1-15. https://doi.org/10.1002/acq3062

Moriarty C (2003) The yellow eel. In: Aida K, Tsukamoto K, Yamauchi K (eds) Eel biology. Springer, Tokyo, pp 89-105

Moriarty C, Dekker W (1997) Management of the European eel. Irish Fish Bull 15:1-125

Naismith IA, Knights B (1988) Migration of elvers and juvenile European eels (Anguilla anguilla L.), in the River Thames. J Fish Biol 33:161-175

Nyman L (1972) Some effects of temperature on eel (Anguilla) behaviour. Rep Inst Freshw Res Drottningholm 52:90-102

Ogden JC (1970) Relative abundance, food habits, and age of the American eel, Anguilla rostrata (LeSeuer), in certain New Jersey streams. Trans Am Fish Soc 99:54-59 
Ovidio M, Seredynski AL, Philippart JC, Matondo BN (2013) A bit of quiet between migrations: the resting phase of the European eel during their freshwater growth phase in a small stream. Aquat Ecol 47:291-301

Pärlklint LG, Bengtsson V (2015) Projekt-ålinventering. Mimeographed report in Swedish

Pedersen MI (2009) Does stocking of Danish lowland streams with elvers increase European Eel populations? In: Casselman JM, Cairns DK (eds) Eels at the edge: science status and conservation concerns. American Fisheries Society, Bethesda, pp 149-156

Piper AT, Wright RM, Kemp PS (2012) The influence of attraction flow on upstream passage of European eel (Anguilla anguilla) at intertidal barriers. Ecol Eng 44:329-336

Prchalová M, Kubečka J, Ř́ha M, Čech M, Jůza T, Ketelaars HAM, Kratochvíl M, Mrkvička T, Peterka J, Vašek M, Wagenvoort AJ (2013) Eel attacks-a new tool for assessing European eel (Anguilla anguilla) abundance and distribution patterns with gillnet sampling. Limnologica Ecol Manag Inland Waters 43(3):194-202

Reid SM (2011) Comparison of point and transect-based electrofishing to sample American eel (Anguilla rostrata) in wadeable riverine habitats. Aquat Living Resour 24:79-83

Reid SM, Haxton TJ (2017) Backpack electrofishing effort and imperfect detection: influence on riverine fish inventories and monitoring. J Appl Ichthyol 33(6):1083-1091

Riley WD, Walker AM, Bendall B, Ives MJ (2011) Movements of the European eel (Anguilla anguilla) in a chalk stream. Ecol Freshw Fish 20:628-635

Schulze T, Kahl U, Radke RJ, Benndorf J (2004) Consumption, abundance and habitat use of Anguilla anguilla in a mesotrophic reservoir. J Fish Biol 65:1543-1562

Scott WB, Crossman EJ (1973) Freshwater fishes of Canada, vol 184. Fisheries Research Board of Canada, Ottawa

Sjöberg NB, Petersson E, Wickström H, Hansson S (2009) Effects of the swimbladder parasite Anguillicola crassus on the migration of European silver eels Anguilla anguillla in the Baltic sea. J Fish Biol 74:2158-2170

Solomon DJ, Beach MH (2004) Fish pass design for eel and elver (Anguilla anguilla). R\&D Technical Report W2-070/ TR1. Bristol, Environment Agency

Sorensen PW (1986) Origin of freshwater attractant(s) of migrating elvers of the American eel, Anguilla rostrata. Environ Biol Fishes 17:185-200

Tamario C, Degerman E, Donadi S, Spjut D, Sandin S (2018) Nature-like fishways as compensatory lotic habitats. River Res Appl 34(3):253-261

Tamario C, Calles O, Watz J, Nilsson PA, Degerman E (2019) Coastal river connectivity and the distribution of ascending juvenile European eel (Anguilla anguilla L.)—implications for conservation strategies regarding fish passage solutions. Aquat Conserv Marine Freshw Ecosyst 2019:1-11. https://doi.org/10.1002/acq.3064

Tesch FW (2003) The eel. Blackwell Science, Oxford

Trigal C, Degerman E (2015) Multiple factors and thresholds explaining fish species distributions in lowland streams. Glob Ecol Conserv 4:589-601

Watz J, Nilsson PA, Degerman E, Tamario C, Calles O (2019) Climbing the ladder: an evaluation of three different anguillid eel climbing substrata and placement of upstream passage solutions at migration barriers. Anim Conserv. https://doi.org/10.1111/acv.12485

Zalewski M, Cowx I (1989) Factors affecting the efficiency of electric fishing. In: Cowx IG, Lamarque P (eds) Fishing with electricity-applications in freshwater. Fisheries management fishing news books. Blackwell Scientific Publications, Oxford, pp 89-111

Publisher's Note Springer Nature remains neutral with regard to jurisdictional claims in published maps and institutional affiliations. 